\author{
KRZYSZTOF GOŁĘBIOWSKI \\ ORCID: 0000-0002-5487-2889 \\ Uniwersytet Wrocławski \\ Instytut Prawa Cywilnego \\ Zakład Prawa Cywilnego i Prawa Międzynarodowego Prywatnego
}

\title{
USTAWOWE WYMOGI STAWIANE NABYWCY PRAWA PODMIOTOWEGO A NABYCIE PRAWA DO MAJĄTKU WSPÓLNEGO MAŁŻONKÓW
}

\begin{abstract}
Abstrakt: W określonych sytuacjach nabycie prawa podmiotowego wymaga, oprócz wystąpienia odpowiedniego zdarzenia prawnego (na przykład zawarcia umowy), spełnienia przez nabywcę szczególnych wymogów, takich jak uzyskanie zezwolenia administracyjnego lub działania w dobrej wierze. W doktrynie i orzecznictwie przyjmuje się przeważnie, że w wypadku małżonków pozostających w ustroju wspólności ustawowej do wejścia prawa do majątku wspólnego wystarczające jest posiadanie odpowiedniej cechy przez jednego tylko małżonka. Teza ta nie zasługuje jednak w pełni na aprobatę, pomija bowiem brzmienie i funkcję przepisów prawnych wprowadzających wspomniane wymogi.
\end{abstract}

Słowa kluczowe: majątek wspólny małżonków, ustrój wspólności ustawowej, nabycie prawa podmiotowego, dobra wiara, nabywanie nieruchomości przez cudzoziemców

\section{ZAKRES ROZWAŻAŃ}

Stosowanie w stosunku do małżonków przepisów prawnych, które wprost nie odnoszą się do ustroju małżeńskiej wspólności ustawowej, często powoduje powstawanie wątpliwości interpretacyjnych. Dotyczą one wszystkich etapów $\mathrm{i}$ aspektów istnienia majątku wspólnego, w tym nabywania praw do niego. Niniejsze opracowanie ma na celu omówienie niektórych problemów pojawiających się przy wykładni przepisów, które uzależniają nabycie prawa podmiotowego od wystąpienia po stronie nabywcy określonych kwalifikacji podmiotowych, takich jak działanie w dobrej wierze, posiadanie odpowiedniego wykształcenia czy uzyskanie zezwolenia administracyjnego w sytuacji, w której nabywca pozostaje w ustroju wspólności majątkowej. 
Rozważania zostaną odniesione przede wszystkim do przepisów ustawy o nabywaniu nieruchomości przez cudzoziemców ${ }^{1}$ oraz art. 169 k.c., jednak ich celem jest sformułowanie reguł o charakterze ogólnym, nadających się do stosowania do innych, podobnych regulacji.

\section{MECHANIZM PRAWNY TWORZENIA MAJĄTKU WSPÓLNEGO}

Wiele problemów wynika ze specyfiki regulacji tworzenia majątku wspólnego małżonków. Podstawowe znaczenie ma w tym zakresie art. $31 \S 1$ zd. 1 k.r.o., który stanowi, że

z chwilą zawarcia małżeństwa powstaje między małżonkami z mocy ustawy wspólność majątkowa (wspólność ustawowa) obejmująca przedmioty majątkowe nabyte w czasie jej trwania przez oboje małżonków lub przez jednego z nich (majątek wspólny).

Prawo podmiotowe wchodzi do majątku wspólnego nie tylko, gdy okoliczności stanowiące stan faktyczny zdarzenia prawnego, powodującego skutek w postaci uzyskania prawa, dotyczyły obojga małżonków, lecz także wtedy, gdy odnosiły się one tylko do jednego z małżonków. Do majątku wspólnego wejdą zatem prawa uzyskane w wyniku dokonania czynności prawnej przysparzającej, jeśli przysporzenie nastąpić miało, zgodnie z treścią danej czynności prawnej (przy uwzględnieniu okoliczności wskazanych w art. 56 k.c.), na rzecz jednego choćby małżonka. Ta sama zasada ma zastosowanie do innych zdarzeń prawnych, na przykład własność nieruchomości wejdzie do majątku wspólnego, nawet jeżeli jej posiadaczem samoistnym był tylko jeden z małżonków ${ }^{2}$. Skutek w postaci wejścia prawa do majątku wspólnego następuje jednocześnie ze ziszczeniem się przesłanek uzyskania prawa, bez potrzeby składania oświadczeń woli przez drugiego małżonka, a nawet bez względu na jego wiedzę o tym fakcie.

Zwłaszcza ostatnia wymieniona cecha mechanizmu tworzenia majątku wspólnego zdaje się powodować powstawanie wątpliwości wspomnianych na wstępie. Chodzi o ustalenie, czy dla wejścia danego prawa do majątku wspólnego

${ }^{1}$ Ustawa z dnia 24 marca 1920 roku (tekst jedn. Dz.U. z 2017 r. poz. 2278); dalej: u.n.n.c. Przepis art. 1 ust. 1 zd. 1 u.n.n.c. stanowi, że „nabycie nieruchomości przez cudzoziemca wymaga zezwolenia”, natomiast zgodnie z jej art. 6 ust. 1 ,nabycie nieruchomości przez cudzoziemca wbrew przepisom ustawy jest nieważne". W pierwotnym brzmieniu u.n.n.c., do którego odnoszą się niektóre z powołanych w dalszej części opracowania orzeczenia i wypowiedzi doktryny, istotne znaczenie miał art. 7 zd. 1 u.n.n.c., który stanowił, że „Nabycie nieruchomości przez cudzoziemca wbrew postanowieniu niniejszej ustawy jest nieważne”. Z kolei art. 1 zd. 1 u.n.n.c. podawał, że „Nabywanie nieruchomości przez cudzoziemców, a to tak przez osoby fizyczne, jak i prawne może nastąpić jedynie po uprzedniem uzyskaniu zezwolenia Ministra Spraw Wewnętrznych, wydanego w porozumieniu z Ministrem Spraw Wojskowych”.

2 Jeżeli koniec biegu zasiedzenia nastąpił w czasie trwania ustroju wspólności; zob. M. Nazar, [w:] System Prawa Prywatnego, t. 11. Prawo rodzinne, red. T. Smyczyński, Warszawa 2014, s. 439. 
konieczne jest występowanie tych cech po stronie obojga małżonków, czy tylko tego z nich, który uczestniczy w danym zdarzeniu prawnym, w szczególności dokonuje czynności prawnej. Zdecydowanie w nauce i orzecznictwie dominuje pogląd, zgodnie z którym wymagane przez ustawę cechy musi posiadać wyłącznie małżonek, którego zachowania prowadzą do nabycia prawa. Zapatrywanie to nie zasługuje jednak w pełni na akceptację. Oparte jest bowiem na nieprzekonującym wyjaśnieniu konstrukcji mechanizmu tworzenia majątku wspólnego oraz na zbyt pobieżnej analizie pojęć „nabycia” i „nabywcy” prawa. Jego konsekwentne stosowanie prowadzi w niektórych wypadkach do rezultatów wprost sprzecznych z celami poszczególnych aktów prawnych, stawiających nabywcom pewnych praw określone wymogi podmiotowe, a niekiedy jest trudne do pogodzenia $\mathrm{z}$ innymi przepisami tych aktów prawnych. Taka wykładnia narusza założenie istnienia racjonalnego prawodawcy.

\section{POGLĄD DOMINUJĄCY}

Zgodnie z dominującym poglądem

wejściu nabytego prawa do majątku wspólnego nie stoi na przeszkodzie okoliczność, że szczególne przesłanki, od których ustawa uzależnia skuteczność nabycia, spełnia tylko jedno z małżonków, mianowicie to, które jest stroną czynności prawnej nabycia lub adresatem aktu, z którego nabycie wynika ${ }^{3}$.

Mimo rozbieżności w sposobie uzasadnienia tego stanowiska przeważnie jednolicie traktuje się wszelkie wymagania stawiane nabywcy prawa, w szczególności kwalifikacje zawodowe, zezwolenia administracyjne czy dobrą wiarę ${ }^{4}$.

Najbardziej pogłębioną analizę problemu przeprowadził A. Dyoniak, który przedstawił dwie skrajne koncepcje, mogące służyć wyjaśnieniu mechanizmu wejścia prawa do majątku wspólnego, a więc „bezpośredniego nabycia prawa”, w której nabywcami są oboje małżonkowie, oraz teorię ,przechodniego nabycia”, zgodnie z którą nabywcą jest małżonek dokonujący czynności prawnej, a „nabycie przez wspólność następuje w chwilę po dokonaniu nabycia przez tego małżonka”. Autor następnie stwierdził, że można przyjąć koncepcję pośrednią — należy

${ }^{3}$ M. Sychowicz, [w:] Kodeks rodzinny i opiekuńczy. Komentarz, red. K. Piasecki, Warszawa 2006, s. 159. Podobnie - w odniesieniu do nabycia nieruchomości przez osobę mającą obywatelstwo polskie, która jest małżonkiem cudzoziemca nieposiadającego zezwolenia Ministra Spraw Wewnętrznych i Administracji - F. Hartwich, Nabycie własności nieruchomości przez cudzoziemca bez zezwolenia, „Monitor Prawniczy” 2002, nr 5, s. 235. J. Ignatowicz wyraził, jak się wydaje, pogląd jeszcze dalej idący, stwierdził bowiem, że do nabycia przedmiotu do majątku wspólnego wystarcza, aby przesłanki te „spełniał tylko jeden z małżonków” - idem, Prawo rodzinne, Warszawa 2000, s. 150.

4 Tak wyraźnie J.S. Piątowski, [w:] System prawa rodzinnego i opiekuńczego, red. J.S. Piątowski, Wrocław 1985, s. 362-363. 
odróżnić nabycie prawa od jego wejścia do majątku wspólnego. Nabywcą prawa na gruncie prawa polskiego ma być jedynie małżonek dokonujący czynności prawnej, natomiast wejście prawa w skład majątku wspólnego jest następującym z mocy prawa skutkiem wynikającym z ustroju wspólności. Podstawę takiego rozróżnienia mają dawać przepisy k.r.o., które odróżniają ,nabycie prawa” od jego „objęcia przez wspólność" (obecnie art. $31 \S 1$ oraz art. 34 k.r.o.) $)^{5}$. W związku z tym tylko małżonek dokonujący czynności prawnej musi posiadać wymaganą przez przepisy dla nabywcy prawa kwalifikację podmiotową.

Z kolei J.S. Piątowski takie okoliczności jak dobra wiara zrównał z uzyskaniem zezwolenia administracyjnego i posiadaniem samoistnym w wypadku zasiedzenia i określił je jako „przesłanki nabycia”. Co godne podkreślenia, zajął w kwestii charakteru mechanizmu wejścia prawa do majątku wspólnego stanowisko odmienne od przedstawionego przez A. Dyoniaka ${ }^{7}$, uznając, że ,nabycie przez drugiego małżonka uprawnień do danego przedmiotu majątkowego [...] następuje jednocześnie z nabyciem ich przez małżonka działającego"8.

Problem możliwości nabycia do majątku wspólnego prawa własności nieruchomości w sytuacji, gdy małżonek - cudzoziemiec, niedokonujący czynności prawnej — nie posiada niezbędnego zezwolenia administracyjnego, był przedmiotem kilku wypowiedzi SN. Za utrwaloną można uznać linię orzecznictwa, zgodnie z którą

zaliczenia nieruchomości nabytej przez jednego z małżonków, będącego obywatelem polskim do majątku objętego małżeńską wspólnością ustawową nie wyłącza jedynie ta okoliczność, że drugi z małżonków jest cudzoziemcem i nie uzyskał zezwolenia na nabycie tej nieruchomości ${ }^{9}$.

Początkowo w uchwale z 24 września 1970 roku wyrażono pogląd o istnieniu luki w prawie, którą należy rozstrzygnąć na korzyść wejścia nieruchomości do majątku wspólnego. Z kolei w uzasadnieniu uchwały z 4 marca 1983 roku Sąd Najwyższy dostrzegł rozbieżność przepisów k.r.o. oraz ustawy o nabywaniu nieruchomości przez cudzoziemców, która objawia się tym, że

5 A. Dyoniak, Ustawowy ustrój majątkowy matżeński, Wrocław 1985, s. 50-51.

6 J.S. Piątowski, op. cit., s. 362-363.

7 Właśnie za pomocą tej konstrukcji A. Dyoniak uzasadniał swój pogląd.

8 J.S. Piątowski, op. cit., s. 362-363. Ten sam autor w wypowiedzi wcześniejszej wyraził jednak niemal identyczny do przedstawionego przez A. Dyoniaka pogląd. Stwierdził mianowicie, że ówcześnie obowiązujący art. 32 § 1 k.r.o. „daje podstawę do tego, aby odróżnić nabycie przedmiotu majątkowego [...] od zaliczenia tego przedmiotu do majątku wspólnego" — idem, Glosa do uchwały Sądu Najwyższego z dnia 24 września 1970 r., III CZP 55/70, „Orzeczenia Sądów Polskich i Komisji Arbitrażowych" 1973, nr 6, poz. 120, s. 257.

9 Tak uchwała SN z dnia 4 marca 1983 roku, sygn. III CZP 6/83, OSNC 1983, nr 8, poz. 114. Podobnie: uchwała SN z dnia 24 września 1970 roku, sygn. III CZP 55/70, OSPiKA 1973, nr 6, poz. 120; uchwała SN z dnia 31 stycznia 1986 roku, sygn. III CZP 70/85, OSNCP 1986, nr 12, poz. 207. 
łatwo dostrzegalne jest zróżnicowanie przesłanek decydujących o skuteczności nabycia własności nieruchomości w czasie obowiązującej małżonków wspólności majątkowej ustawowej, gdy jeden z nich będący cudzoziemcem nie uzyskał zezwolenia na nabycie tej nieruchomości, a drugi z małżonków nabywa ją w warunkach uzasadniających zaliczenie tej nieruchomości do majątku dorobkowego (art. 32 k.r.o.).

\section{Następnie wywiedziono, że}

o zaliczeniu nabytego przez jednego z małżonków przedmiotu do obowiązującego małżonków ustroju wspólności majątkowej nie rozstrzyga treść tej czynności lub wola działającego małżonka. Skutek taki następuje z mocy samego prawa i stanowi rezultat wynikający z samej istoty ustawowej wspólności majątkowej. Jeżeli zatem nabywcą jest tylko jeden z małżonków, ocena skuteczności nabycia dotyczy tylko osoby tego nabywcy.

Uprzedzając tok wywodów, można zauważyć, że istota problemu leży właśnie w tym, czy w analizowanej sytuacji nabywcą jest jedno z małżonków, czy jednak oboje.

W nowszym orzecznictwie podtrzymano ten kierunek wykładni, a raczej ten kierunek rozstrzygnięć. W uzasadnieniu uchwały z 18 maja 1995 roku ${ }^{10}$ stwierdzono, że

przepisy o wspólności ustawowej nie zawierają wymagania, aby szczególne przesłanki, od których ustawa uzależnia skuteczność nabycia prawa, były spełnione przez oboje małżonków. [...] inaczej jednak będzie wtedy, gdy nabywcą nieruchomości będzie małżonek będący obywatelem polskim albo gdy nabywcami są oboje małżonkowie o mieszanym obywatelstwie (polskim i obcym). W takim wypadku należy dać pierwszeństwo przepisom prawa rodzinnego, a w konsekwencji uznać skuteczność nabycia nieruchomości i objęcia jej wspólnością ustawową, pomimo że małżonek-cudzoziemiec nie uzyskał wymaganego zezwolenia.

Dominujący pogląd został poddany krytyce przez A. Berezę ${ }^{11}$, jednak — jak się wydaje - przede wszystkim ze względu na zmiany, jakie zaszły w regulacji nabywania nieruchomości przez cudzoziemców na podstawie ustawy z 15 marca 1996 roku $^{12}$. Wprowadziła ona do tego aktu prawnego art. 8 ust. 1 pkt 3, wyjątkowo zwalniający z obowiązku uzyskania zezwolenia w niektórych spośród sytuacji, w których nieruchomość ma wejść do majątku wspólnego małżonków — zatem a contrario inne przypadki takiego nabycia powinny być objęte wymogiem uzyskania zezwolenia. Autor podniósł także argumenty o sprzeczności dominującej wykładni z celami ustawy i nieracjonalności wymagania zezwolenia na samo dokonanie czynności nabycia. Pogląd wyrażony przez A. Berezę nie zyskał jednak szerszej akceptacji ${ }^{13}$.

10 Sygn. III CZP 58/95, OSNC 1995, nr 10, poz. 139.

11 A. Bereza, Nabycie nieruchomości do majątku objętego matżeńska wspólnościa ustawowa, jeżeli jeden z matżonków ma status cudzoziemca, „Rejent” 2004, nr 3-4, s. 106-115.

12 Ustawa z dnia 15 marca 1996 roku o zmianie ustawy o nabywaniu nieruchomości przez cudzoziemców (Dz.U. z 1996 r. Nr 45, poz. 198).

13 Jednoznacznie stanowisko tradycyjne poparł między innymi G. Jędrejek, który stwierdził: „Przepisy ww. ustawy w ogóle nie mają zastosowania do opisanej wyżej sytuacji. Regulują one 
Również w orzecznictwie stanowisko odmienne od dominującego jest odosobnione. W uzasadnieniu wyroku NSA z 25 lutego 2002 roku $^{14}$ stwierdzono, że

współwłasność nieruchomości tak w częściach ułamkowych, jak i współwłasność łączna jest własnością nieruchomości w rozumieniu art. 140 k.c. [...]. Oznacza to, że także nabycie własności nieruchomości przez cudzoziemca w charakterze współwłaściciela jest „nabyciem nieruchomości” w rozumieniu powołanego przepisu art. 1 ust. 1 ustawy z 24 marca 1920 r. o nabywaniu nieruchomości przez cudzoziemców, wymagającym przewidzianego w tym przepisie zezwolenia Ministra Spraw Wewnętrznych.

\section{POJĘCIA „NABYCIA” I „NABYWCY”}

Istota problemu analizowanego w niniejszym opracowaniu leży we właściwym ujęciu skutku, który zachodzi w momencie wejścia prawa podmiotowego do majątku wspólnego ${ }^{15}$. Warto zatem podjąć próbę sprecyzowania znaczenia pojęć „nabycie” i „nabywca”.

Wypowiedzi doktryny najczęściej sprowadzają się do analizy poszczególnych przypadków nabycia prawa lub usystematyzowania ich według określonych kryteriów. Samo „nabycie” rozumie się intuicyjnie jako termin niewymagający szerszego wyjaśniania. Z rozważań poszczególnych autorów można jednak wywnioskować, że „nabycie prawa” jest tym samym co jego „uzyskanie”, „przypisanie prawa konkretnemu podmiotowi”, ,powiązanie prawa z określonym podmiotem”16. Podążając za sugestią Z. Radwańskiego ${ }^{17}$, trzeba stwierdzić, że „nabycie prawa podmiotowego" to sytuacja, w której — na skutek wystąpienia zdarzenia prawnego

bowiem, zgodnie z nazwą, nabywanie nieruchomości przez cudzoziemców, a nie przez osoby, które pozostają z cudzoziemcami w stosunkach rodzinnych" — idem, Nabycie własności nieruchomości przez matżonka będącego cudzoziemcem, „Nieruchomości” 2008, nr 11, s. 13. Podobnie M. Nazar, op. cit., s. 415. Tezy autora poparła natomiast I. Wereśniak-Masri, Nabywanie nieruchomości przez cudzoziemców w Polsce, Warszawa 2017.

14 Sygn. V SA 1909/01, LEX nr 109334.

15 Charakterystyczna jest w tym zakresie wypowiedź M. Nazara, który stwierdził, że „Nabywcą prawa (w technicznoprawnym znaczeniu) jest małżonek dokonujący czynności prawnej, natomiast wejście prawa do majątku wspólnego jest następującym ex lege skutkiem prawnym istnienia ustroju wspólności ustawowej [...]. Wobec tego można twierdzić, że szczególne ustawowe wymagania dotyczące nabycia prawa do majątku wspólnego powinien spełnić małżonek, który prawo nabywa. [wyr. oryg.] Prawo nabyte skutecznie przez jednego małżonka powinno być uznane za składnik majątku wspólnego, choćby drugi małżonek nie spełniał ustawowych wymogów nabycia prawa" - idem, op. cit., s. 415.

16 Z. Radwański, Prawo cywilne - część ogólna, Warszawa 2005, s. 104 n.; M. Pyziak-Szafnicka, [w:] System Prawa Prywatnego, t. 1. Prawo cywilne - część ogólna, red. M. Safjan, Warszawa 2007, s. 753.

17 Autor stwierdza, że „problematyka nabycia i utraty prawa podmiotowego sprowadza się do powiązania tego prawa z określoną osobą. Gdy ktoś prawo nabywa, związek jego z prawem powstaje, a gdy je traci, związek ten ustaje" — Z. Radwański, op. cit., s. 104. 
— określony podmiot uzyskuje prawo podmiotowe, a więc następuje „przypisanie” prawa temu podmiotowi. Określeniem tym opisuje się więc sytuację, w której można wyróżnić dwa momenty: pierwszy, w którym podmiotowi nie przysługuje prawo podmiotowe, i następujący po nim drugi, w którym prawo to mu już przysługuje. Można zaproponować uznanie tego znaczenia za podstawowe, ścisłe.

Ponadto słowo „nabycie” występuje niekiedy w języku prawnym i prawniczym dla opisania pewnej działalności i oznacza zachowanie (zwłaszcza dokonanie czynności prawnej), które ma prowadzić do uzyskania prawa podmiotowego, bez względu na jego skutek prawny. „Nabywać prawo” w tym znaczeniu to tyle co podejmować czynności zmierzające od jego uzyskania, do wywołania skutku prawnego $\mathrm{w}$ postaci przypisania działającemu podmiotowi prawa podmiotowego (a więc do nabycia w znaczeniu pierwszym).

Analogiczne uwagi należy odnieść do pojęcia „nabywcy” — może ono oznaczać osobę, która uzyskała określone prawo albo podmiot zdarzenia prawnego mającego doprowadzić do jego nabycia. W drugim wypadku działający podmiot jest „nabywcą” (to znaczy — jest tak określany przez przepis prawny) bez względu na to, czy rzeczywiście doszło do uzyskania przez niego prawa podmiotowego, a więc czy stał się ,nabywcą" w pierwszym znaczeniu.

Warto wskazać przykłady występowania w przepisach prawnych różnych znaczeń omawianych pojęć. Zgodnie z art. 171 § 1 k.c.

posiadacz nieruchomości niebędący jej właścicielem nabywa własność, jeżeli posiada nieruchomość nieprzerwanie od lat dwudziestu jako posiadacz samoistny, chyba że uzyskał posiadanie w złej wierze (zasiedzenie).

Posiadacz samoistny uzyskuje prawo własności, czyli „,nabywa” je w pierwszym opisanym znaczeniu. W tym (podstawowym) znaczeniu analizowany termin występuje w licznych przepisach, na przykład art. 554, art. 181 oraz art. 221 k.c.

Terminy „nabycie” $\mathrm{i}$,nabywca” występują w aktach prawnych również w drugim z podanych znaczeń. W szczególności, zgodnie z art. $155 \S 1$ k.c.,

umowa sprzedaży, zamiany, darowizny lub inna umowa zobowiązująca do przeniesienia własności rzeczy co do tożsamości oznaczonej przenosi własność na nabywcę, chyba że przepis szczególny stanowi inaczej albo że strony inaczej postanowiły.

W sytuacji gdy strony „inaczej postanowią"18, „nabywca” nie uzyska własności, a więc - posługując się terminologią użytą w przepisie — „umowa nie przeniesie własności” właśnie na „nabywcę”. „Nabywca” to strona jednej z umów opisanych w treści przepisu, a nie osoba, która uzyskała prawo własności. W takim samym znaczeniu określenie „nabywca” występuje w art. 169 § 1 k.c.

Ustawodawca w niektórych wypadkach posługuje się zatem terminem ,nabywca" na określenie osoby, która dokonuje pewnej czynności zmierzającej do

18 Wyłącza więc tak zwany podwójny skutek umowy zobowiązującej do przeniesienia własności. 
uzyskania prawa podmiotowego, bez względu na skutek tego działania. Samo natomiast nabycie prawa określane jest wówczas — inaczej niż w wypadku art. 172 $\S 1$ k.c. — jako jego „uzyskanie” lub „przejście” na nabywcę.

\section{KWALIFIKACJA WEJŚCIA PRAWA DO MAJĄTKU WSPÓLNEGO W WYNIKU WYSTĄPIENIA ZDARZEŃ PRAWNYCH DOTYCZĄCYCH JEDNEGO TYLKO MAŁŻONKA}

Warto poświęcić uwagę tezie A. Dyoniaka ${ }^{19}$ o potrzebie odróżnienia „nabycia prawa przez małżonka” od jego „wejścia w skład majątku wspólnego”. Właśnie ta koncepcja pozwala - zgodnie z poglądami niektórych autorów i uzasadnieniami niektórych orzeczeń $\mathrm{SN}$ - na niestosowanie w stosunku do małżonka nieuczestniczącego w czynności prawnej ograniczeń podmiotowych ustanowionych w normach prawnych dla „nabywcy” prawa. Zdaje się ona wprawdzie pozostawać w zgodzie z dosłownym brzmieniem art. $31 \S 1$ k.r.o. (dawniej art. 32 k.r.o.), jednak budzi poważne wątpliwości.

Podmiotami praw należących do majątku wspólnego są wyłącznie małżonkowie. Natomiast majątek to zbiór praw podmiotowych danej osoby ${ }^{20}$. Jeżeli w chwili nabycia prawa podmiotowego przez jednego z małżonków następuje „objęcie go” przez majątek wspólny czy „wejście prawa do wspólności (majątku

19 Popartej także w niektórych przynajmniej wypowiedziach przez J.S. Piątowskiego — idem, Glosa do uchwaty Sadu Najwyższego..., s. 247.

${ }^{20}$ Istotę zagadnienia wyczerpująco wyjaśnił M. Nazar. Przejrzystość, stanowczość i trafność tej wypowiedzi uzasadnia szersze jej przytoczenie: „podmiotami wszystkich praw tworzących wspólny majątek są oboje małżonkowie, bez względu na to, czy prawo zostało nabyte przez jednego małżonka lub oboje małżonków. Nabycie przez jednego małżonka prawa podmiotowego podlegającego zaliczeniu do majątku wspólnego powoduje wejście tego prawa do majątku wspólnego [...]. Jeżeli majątek tworzy ogół praw podmiotowych przysługujących określonej osobie lub współuprawnionym osobom (majątek wspólny), to status podmiotu majątku równoznaczny jest ze statusem strony stosunków cywilnoprawnych, których elementem treści są prawa podmiotowe tworzące ten majątek, także - wielopodmiotowy, objęty wspólnością. Majątek wspólny, do którego wchodzi prawo nabyte wyłącznie przez jednego małżonka, nie staje się bowiem, w miejsce stosunku prawnego "zastępczą ramą« dla nabytego prawa podmiotowego. Sam jest bowiem funkcjonalnym zespoleniem praw podmiotowych istniejących w ramach określonych stosunków cywilnoprawnych. Majątku objętego wspólnością nie można więc uznać za przedmiot jakiegoś odrębnego stosunku prawnego, w którym jedną stroną byłyby podmioty wspólnego majątku, drugą zaś wszystkie pozostałe podmioty tworzące strony stosunków prawnych, z których pochodziłyby nabyte do majątku prawa podmiotowe. Prawa podmiotowe tworzące majątek, w szczególności - objęty wspólnością, istnieją więc nadal jako elementy treści określonych stosunków prawnych. Gdy zatem tylko jeden z małżonków (nie reprezentując drugiego małżonka na podstawie pełnomocnictwa) zawiera umowę powodującą nabycie prawa i jego wejście do majątku wspólnego, to drugi małżonek będący podmiotem majątku wspólnego staje się także podmiotem nabytego prawa i stroną stosunku cywilnoprawnego, którego elementem jest nabyte prawo" - idem, op. cit., s. 283-284. Zob. także K. Gołębiowski, Zarząd majątkiem wspólnym matżonków, Warszawa 2012, s. 27-53, 74-79. 
wspólnego)", to w tym właśnie momencie drugi małżonek nabywa to prawo ${ }^{21}$. Od chwili nabycia prawa przez „działającego" małżonka oboje małżonkowie są podmiotami tego prawa, na przykład współwłaścicielami kupionego wyłącznie przez żonę samochodu. Sytuację, w której przed wystąpieniem określonego zdarzenia dana osoba nie była podmiotem określonego prawa, a na skutek jego wystąpienia jest podmiotem tego prawa (zostało jej ono przypisane, uzyskała je, prawo weszło do jej majątku), określa się właśnie jako „nabycie prawa podmiotowego” w ścisłym, pierwszym z podanych wcześniej, znaczeniu.

„Skład majątku” to ogół przysługujących określonej osobie praw majątkowych. „Powiększenie się składu majątku osoby A o prawo podmiotowe” to nic innego jak powiększenie się liczby praw podmiotowych przysługujących podmiotowi A. Konsekwentnie, stwierdzenie, że „określone prawo weszło do majątku podmiotu A”, oznacza dokładnie to samo co zdanie „A naby $2^{22}$ określone prawo”. Eksponowana $\mathrm{w}$ doktrynie rozbieżność znaczeń jest więc pozorna i stanowi nieuprawnioną ,grę słów”. Ustawodawca w różnych przepisach prawnych opisuje bowiem skutek w postaci nabycia prawa podmiotowego za pomocą różnych określeń23 i dlatego sam fakt użycia w art. $31 \S 1$ k.r.o. słowa „obejmująca” nie powinien stanowić podstawy konstruowania pojęcia ,uzyskania prawa bez jego nabycia poprzez objęcie go majątkiem danej osoby".

Podsumowując, należy wskazać, że bez względu na to, który z małżonków podjął czynność lub którego z małżonków dotyczyło zdarzenie prawne powodujące nabycie prawa podmiotowego do majątku wspólnego, oboje małżonkowie są nabywcami tego prawa w ścisłym znaczeniu ${ }^{24}$. Jeśli stosowne działania podjął tylko jeden z nich, można o nim mówić jako o ,jedynym nabywcy” tego prawa tylko z zaznaczeniem, że chodzi o drugie znaczenie zwrotu „nabywca”.

\section{KONSEKWENCJE PRZYJĘTEGO POGLĄDU}

\subsection{REGUŁA OGÓLNA}

Nie można zaakceptować przyjmowanego bez szerszego uzasadnienia założenia, że wszystkie przepisy wprowadzające „wymogi podmiotowe” nabycia prawa odnoszą się do „nabycia” w tym samym znaczeniu i w związku z tym wszystkie podlegają rozstrzygnięciu na tej samej zasadzie. Charakter tych wymogów

$21 \mathrm{~W}$ pierwszym, podstawowym znaczeniu.

$22 \mathrm{~W}$ podstawowym znaczeniu tego słowa.

${ }^{23}$ Na przykład użyte w art. 169 § 1 i art. 172 k.c. słowa „,nabywa” i „,uzyskuje” mimo różnego brzmienia mają identyczne znaczenie prawne.

${ }^{24}$ Ze wszystkimi konsekwencjami tego stwierdzenia, w szczególności w postaci konieczności spełniania przez oboje małżonków wymagań stawianych przez przepisy prawne nabywcom określonych praw podmiotowych. 
i sposób ich wyrażenia w przepisach prawnych pozwala na wyróżnienie dwóch ich grup o zasadniczo odmiennym charakterze - pierwsza odwołuje się do cech podmiotu, który ma uzyskać prawo, druga — do sposobu działania prowadzącego do uzyskania prawa.

Z założenia racjonalności prawodawcy wynika, że gdy osobie mającej nabyć (uzyskać) prawo podmiotowe ustawa stawia wymóg posiadania pewnych kwalifikacji, który ma gwarantować wykonywanie prawa w sposób pożądany przez ustawodawcę $e^{25}$, to taki wymóg powinien być zastosowany wobec każdej osoby, która ma uzyskać prawo. Innymi słowy, jeśli uzyskanie określonego prawa jest warunkowane istnieniem pewnych właściwości dotyczących samej osoby nabyw$\mathrm{cy}^{26}$, oczywiste jest, że nie powinno dojść do jego nabycia przez osobę, która nie posiada tych właściwości. Teza ta nie budzi wątpliwości w odniesieniu do nabywania własności nieruchomości przez cudzoziemców na zasadach wspólności ułamkowej ${ }^{27}$. Powinna być tym bardziej odniesiona do małżonka, który miałby stać się współwłaścicielem nieruchomości w ramach majątku wspólnego na skutek działań podjętych przez drugiego małżonka.

W wypadku natomiast gdy nabycie (uzyskanie) prawa podmiotowego jest uzależnione nie od pewnych cech osoby nabywcy, ale od cech podejmowanego przez tę osobę działania, właściwości te musi wykazywać tylko ten małżonek, który dokonuje odpowiedniej czynności. Dotyczy to przede wszystkim przepisów pozwalających na nabycie prawa podmiotowego osobie działającej w dobrej wierze.

Wprawdzie ze względów technicznoprawnych okoliczności podmiotowe istotne dla obu kategorii przepisów muszą wystąpić w ostatnim czasowo elemencie stanu faktycznego prowadzącego do nabycia prawa, warto jednak zwrócić uwagę na ich zasadniczo odmienny charakter. W wypadku przepisów chroniących dobrą wiarę w obrocie istotny jest sposób postępowania sprzed nabycia prawa (w szczególności stan wiedzy nabywcy), a jego późniejsze zachowania są zasadniczo irrelewantne ${ }^{28}$. Natomiast wymogi odniesione do nabywcy w ścisłym znaczeniu tego słowa nie tylko nie opisują sposobu jego działania, lecz nadto są funkcjonalnie ukierunkowane

${ }^{25}$ Na przykład bez narażenia interesu państwa w wypadku własności nieruchomości wykonywanej przez cudzoziemca albo zgodnie z zasadami wiedzy agrotechnicznej w odniesieniu do nieruchomości rolnych; zob. np. preambułę i art. 6 ustawy z dnia 11 kwietnia 2003 roku o kształtowaniu ustroju rolnego (tekst jedn. Dz.U. z 2019 r. poz. 1362).

${ }^{26}$ Nawet jeśli przepis nie odnosi się wprost do tych właściwości, lecz do istnienia decyzji administracyjnej, której wydanie uzależnione jest od występowania takich właściwości.

27 Tak np. I. Wereśniak-Masri, op. cit.

28 Wyjątek w tym zakresie stanowi, zgodnie z przeważającym dotąd stanowiskiem, sytuacja mogąca wystąpić przy stosowaniu art. 169 § 2 k.c.; tak np. A. Stelmachowski, [w:] System Prawa Prywatnego, t. 3. Prawo rzeczowe, red. T. Dybowski, Warszawa 2007, s. 357-358. W nowszych wypowiedziach coraz szersze poparcie zyskuje jednak pogląd odmienny, zgodnie z którym pozostawanie nabywcy w dobrej wierze w czasie biegu ustanowionego w tym przepisie terminu nie jest przesłanką nabycia własności; zob. K. Gołębiowski, [w:] Kodeks cywilny. Komentarz, red. E. Gniewek, P. Machnikowski, Warszawa 2019, s. 408-409 i powołana tam literatura. 
na przyszłość. W szczególności pozytywna decyzja administracyjna oparta będzie między innymi na pozytywnej prognozie co do zachowania przyszłego właściciela nieruchomości (art. 1a ust. 1 i 2 u.n.n.c.).

\subsection{NABYWANIE NIERUCHOMOŚCI PRZEZ CUDZOZIEMCÓW}

Rozważania szczegółowe wypada rozpocząć od regulacji ustawy o nabywaniu nieruchomości przez cudzoziemców. Dominujący pogląd głosi, że w sytuacji gdy stroną umowy prowadzącej do nabycia własności nieruchomości jest małżonek posiadający obywatelstwo polskie, prawo własności nieruchomości wchodzi do majątku wspólnego, nawet jeśli małżonek-cudzoziemiec nie ma odpowiedniego zezwolenia. Stanowisko to opierane jest najczęściej na stwierdzeniu, że ze względu na to, iż „nabywcą jest tylko osoba zawierająca umowę”, wymóg uzyskania zezwolenia nie odnosi się do jej współmałżonka.

Kluczowe do rozstrzygnięcia analizowanego problemu jest ustalenie znaczenia, w jakim ustawodawca posługuje się zwrotem „nabycie” w art. 1 ust. 1 u.n.n.c., a więc czy zezwolenie jest konieczne do dokonania czynności prowadzącej do nabycia (zawarcia umowy, wykonywania posiadania samoistnego), czy też do samego uzyskania prawa podmiotowego. Nie ma trzeciej możliwości interpretacji omawianych przepisów. Zgodnie z dominującym poglądem chodzi tu o nabycie jako pewną czynność, a co za tym idzie cudzoziemiec jest zobowiązany uzyskać zezwolenie na podjęcie zachowań zmierzających do nabycia (uzyskania) prawa podmiotowego. Artykuł 1 ust. 4 ustawy rozwiewa jednak wątpliwości co do znaczenia terminu „nabycie” w tym akcie prawnym. Wyraźnie odgranicza bowiem nabycie (jako skutek prawny) od zdarzenia prawnego je powodującego; przepis stanowi przecież o „nabyciu na podstawie zdarzenia prawnego”. I właśnie takie „nabycie na podstawie każdego zdarzenia prawnego" przez cudzoziemca wymaga, stosownie do treści art. 1 ust. 1 ustawy, zezwolenia. Zezwolenie jest wymagane do „nabycia” (uzyskania) prawa podmiotowego, a nie do wystąpienia „zdarzenia prawnego" (na przykład dla zawarcia umowy). W art. 1 ust. 1 ustawy chodzi więc o nabycie w ścisłym tego słowa znaczeniu. Cudzoziemiec musi w związku tym uzyskać zezwolenie, aby mógł nabyć (uzyskać) prawo własności lub użytkowanie wieczyste $^{29}$ nieruchomości położonej w Polsce. W wypadku małżonków, z których jeden jest cudzoziemcem, oznacza to, że bez względu na okoliczność, który z nich dokonuje czynności (na przykład który zawiera umowę) mającej doprowadzić do nabycia nieruchomości, do wejścia prawa własności lub użytkowania wieczystego do majątku wspólnego małżonków, czyli do nabycia własności przez cudzoziemca, konieczne jest uzyskanie przez niego zezwolenia administracyjnego.

29 Aby stać się podmiotem jednego z tych praw. 
Na trafność przedstawionej koncepcji wskazuje także wykładnia funkcjonal$\mathrm{na}^{30}$. Zgodnie $\mathrm{z}$ dominującym poglądem, gdyby stroną umowy prowadzącej do nabycia własności był małżonek-cudzoziemiec, do wejścia prawa do wspólności majątkowej małżeńskiej konieczne byłoby uzyskanie zezwolenia administracyjnego $^{31}$. Natomiast w sytuacji gdy czynności tej dokonuje małżonek o polskim obywatelstwie, zezwolenie nie jest konieczne. Należałoby zatem przyjąć, że ustawodawca, uchwalając omawianą ustawę oraz utrzymując ją przez niemal sto lat w systemie prawnym, miał na celu kontrolowanie uczestniczenia w zawieraniu umów prowadzących do nabycia nieruchomości przez cudzoziemców. Celem ustawy byłaby w takim ujęciu bliżej nieokreślona ochrona notariatu przed cudzoziemcami. Wniosek ten jest nie tylko absurdalny, ale pozostaje w sprzeczności $\mathrm{z}$ uregulowaniami ustawy. $\mathrm{Z}$ jej przepisów, zwłaszcza określających przesłanki wydania zezwolenia, wynika bowiem, że ustawodawca nie wprowadził wymogu uzyskania zezwolenia w celu ochrony pracowników kancelarii notarialnych, a wzmocnienia kontroli nad stosunkami własnościowymi dotyczącymi nieruchomości.

Przykładowo art. 1a ust. 1 u.n.n.c. stanowi, że zezwolenie jest wydawane, jeżeli ,nabycie nieruchomości przez cudzoziemca nie spowoduje zagrożenia obronności, bezpieczeństwa państwa lub porządku publicznego, a także nie sprzeciwiają się temu względy polityki społecznej i zdrowia społeczeństwa” i „wykaże on, że zachodzą okoliczności potwierdzające jego więzi z Rzecząpospolitą Polską". Przyjmując założenie racjonalności ustawodawcy, należy uznać, że takie sformułowanie przesłanek wydania zezwolenia wyraźnie wskazuje, że jest ono niezbędne do stania się właścicielem nieruchomości, a nie do stania się stroną umowy. Trudno wyobrazić sobie bowiem sytuację, w której złożenie przed notariuszem oświadczenia woli miałoby zagrażać bezpieczeństwu państwa, natomiast zupełnie inaczej należy ocenić stan, w którym określony podmiot pozostaje właścicielem nieruchomości.

Za proponowanym sposobem wykładni przemawia ponadto uregulowanie art. 3e ustawy, które rozciąga ograniczenia w nabywaniu praw podmiotowych przez cudzoziemców na uzyskiwanie udziałów w spółkach, które są właścicielami nieruchomości. Oznacza to, że nawet spowodowanie skutku w postaci tego rodzaju „pośredniego" przysługiwania własności cudzoziemcowi jest objęte obowiązkiem uzyskania zezwolenia. Warto przy tym podkreślić, że w wypadku „wejścia” prawa własności do majątku wspólnego małżonków prawo to przysługuje małżonkowi (cudzoziemcowi) „bezpośrednio”, z tym że w ramach wspólności łącznej.

${ }^{30}$ Ma to szczególne znaczenie dla oceny dawniejszych wypowiedzi doktryny i orzecznictwa, w pierwotnym brzmieniu u.n.n.c. nie występował bowiem odpowiednik obecnego art. 1 ust. 4 .

31 J.S. Piątowski stwierdził, iż ,nie powinno budzić z drugiej strony wątpliwości, że bezskuteczne byłoby nabycie nieruchomości bez zezwolenia przez cudzoziemca, który pozostaje w związku małżeńskim z obywatelką polską" — idem, Glosa do uchwaty Sądu Najwyższego..., s. 258. 
Odnosząc się do podnoszonego w jednym z orzeczeń SN argumentu o roli, jaką małżeńska wspólność ustawowa odgrywa w umocnieniu małżeństwa, wypada postawić pytanie, czy stanowisko dopuszczające nabycie własności nieruchomości z pominięciem obowiązku uzyskania zezwolenia dla cudzoziemca będącego małżonkiem obywatela polskiego nie prowadzi właśnie do deprecjonowania wartości małżeństwa przez pośrednie zachęcanie do zawierania małżeństw jedynie w celu obejścia ustawowego zakazu.

Należy zgodzić się z tezą A. Berezy o tym, że obowiązywanie art. 8 ust. 1 pkt 3 u.n.n.c. a contrario potwierdza, że uzyskanie zezwolenia jest niezbędne w innych niż wskazany w tym przepisie wypadkach, w których nabywane nieruchomości „stanowić będą wspólność ustawową małżonków”, z których jeden jest cudzoziemcem w rozumieniu ustawy. Taka wykładnia była jednak uzasadniona także przed wejściem w życie obszernej nowelizacji, wprowadzającej wskazany przepis.

\subsection{WYJĄTKI OD ZASADY NEMO PLUS IURIS}

Cechą wspólną przepisów pozwalających na nabycie prawa podmiotowego od osoby nieuprawnionej ${ }^{32}$ jest przesłanka występowania po stronie nabywcy kwalifikacji podmiotowej w postaci dobrej wiary. Do rozważenia pozostaje kwestia, czy wymaganie dobrej wiary w wypadku małżonków pozostających w ustroju wspólności majątkowej małżeńskiej dotyczy ich obojga, czy tylko jednego z nich, tego mianowicie, który samodzielnie dokonuje ocenianej czynności prawnej ${ }^{33}$.

Zgodnie z niespornym $\mathrm{w}$ zasadzie stanowiskiem doktryny i orzecznictwa, jeżeli dany przepis nie zawiera definicji legalnej tego pojęcia, w dobrej wierze działa ten, kto pozostaje w błędnym, aczkolwiek usprawiedliwionym przekonaniu o istnieniu bądź nieistnieniu określonej treści stosunku prawnego ${ }^{34}$. Przekonanie to jest usprawiedliwione, jeżeli osoba ta nie mogła przy dołożeniu należytej staranności uzyskać wiadomości co do rzeczywistego stanu prawnego.

Oceny istnienia dobrej wiary dokonuje się przez zbadanie, czy osoba działająca w celu nabycia prawa podmiotowego wiedziała o rzeczywistym stanie prawnym, a w razie ustalenia - co wobec trudności dowodowych będzie regułą - że wiedzy takiej nie posiadała, przez zbadanie, czy podjęła wymagane w danej sytuacji akty staranności w celu poznania rzeczywistego stanu prawnego.

32 Wyliczenie przepisów ustanawiających wyjątki od zasady nemo plus iuris in alium transferre potest quam ipso habet w: A. Wolter, J. Ignatowicz, K. Stefaniuk, Prawo cywilne. Zarys części ogólnej, Warszawa 2002, s. 145-146.

33 Jeżeli oboje dokonują tej czynności wspólnie, omawiany problem nie powstaje, zła wiara jednego z nabywających wyłącza możliwość nabycia prawa; podobnie: P. Machnikowski, [w:] Kodeks cywilny. Komentarz, s. 29.

34 E. Gniewek, Kodeks cywilny. Ksiega druga. Własność i inne prawa rzeczowe. Komentarz, Kraków 2001, s. 268-269; P. Machnikowski, op. cit., s. 28-29. 
Warto więc podkreślić, że w sensie normatywnym nie jest możliwe badanie dobrej bądź złej wiary współmałżonka osoby samodzielnie dokonującej czynności prawnej mającej doprowadzić do nabycia własności z osobą nieuprawnioną do rozporządzania nią. Dochowanie należytej staranności polega bowiem, zależnie od okoliczności konkretnego przypadku, na sprawdzeniu uprawnień osoby występującej jako zbywca, podjęciu działań w celu rozwiania istniejących wątpliwości, odwołaniu się do istniejących rejestrów ${ }^{35}$. Skoro drugi małżonek nie uczestniczy w czynności nabycia rzeczy ruchomej, a często w ogóle nie wie o dokonywanym przez jej współmałżonka nabyciu, nie można oczekiwać od niego podejmowania jakichkolwiek aktów staranności.

We wszystkich przepisach ustanawiających wyjątki od zasady nemo plus iuris określenie „,nabywca w dobrej wierze”36 — o ile występuje — oznacza osobę, która dokonuje pewnej czynności. Do nabycia prawa podmiotowego konieczne i zarazem wystarczające jest występowanie dobrej wiary jedynie po stronie małżonka działającego, to znaczy zawierającego umowę, co wprost wynika z treści przepisu („chyba że działa w złej wierze”37; drugi małżonek nie „działa” w rozumieniu tej regulacji, a więc nie ma potrzeby badania jego dobrej wiary). Spełnienie w stosunku do niego przesłanek zastosowania danego przepisu stanowiącego wyjątek od zasady nemo plus iuris doprowadzi — z mocy regulacji art. $31 \S 1$ k.r.o. — do nabycia tego prawa również przez drugiego małżonka. Ewentualna zła wiara tego ostatniego nie ma wpływu na skuteczność nabycia prawa na podstawie omawianej grupy przepisów ${ }^{38}$.

Pozostaje rozważenie możliwości wzięcia pod uwagę przy ocenie skuteczności nabycia na podstawie art. 169 § 1 k.c. złej wiary niedziałającego małżonka, polegającej na pozytywnej wiedzy o nieposiadaniu uprawnienia do rozporządzania prawem własności przez zbywcę. Właśnie sytuacja, w której mąż wie, że zbywca nie jest właścicielem rzeczy, natomiast żona dokonująca czynności prawnej prowadzącej do nabycia własności pozostaje w dobrej wierze co do tego faktu, może budzić wątpliwości natury moralnej. W takiej sytuacji mąż skorzystałby niejako z niewiedzy czy braku orientacji w stanie prawnym po stronie żony.

Można zresztą założyć wystąpienie sytuacji, w której małżonek posiadający pozytywną wiedzę o rzeczywistym stanie prawnym nakłania współmałżonka do dokonania czynności prawnej zmierzającej do nabycia prawa własności rzeczy ruchomej od nieuprawnionego, licząc na skuteczność takiej czynności wobec dobrej wiary współmałżonka. Pomijając wątpliwości co do możliwości wystąpienia takiej sytuacji w praktyce, wypada zwrócić uwagę na problem ciężaru dowodu. Gdyby osobie kwestionującej wystąpienie nabycia własności (w typowej sytuacji

35 A. Szpunar, Nabycie własności ruchomości od nieuprawnionego, Kraków 1999, s. 104-109.

${ }^{36}$ Lub określenie podobne, wskazujące na wymóg istnienia dobrej wiary u osoby dokonującej czynności prawnej.

37 Podobnie np. art. $83 \S 2$ k.c., art. $6 \S 1$ u.k.w.h.

38 A. Szpunar, op. cit., s. 173. 
dawnemu właścicielowi ruchomości) udało się wykazać istnienie wiedzy niedziałającego małżonka o rzeczywistym stanie prawnym, powstałoby - najczęściej trudne do podważenia - domniemanie faktyczne istnienia takiej wiedzy także po stronie małżonka dokonującego czynności prawnej. Możliwości ukształtowania stanów faktycznych nie są łatwe do przewidzenia i każdą sprawę należy traktować indywidualnie, jednak trudno wyobrazić sobie wystąpienie w praktyce sytuacji, w których strona procesu będzie w stanie wykazać, iż niedziałający małżonek posiadał pozytywną wiedzę na temat istniejącego stanu prawnego, a nie będzie w stanie udowodnić choćby niedochowania należytej staranności po stronie małżonka uczestniczącego w czynności prawnej.

\title{
PODSUMOWANIE
}

Problemy wynikające z samej konstrukcji wspólności i zasad jej powstawania nie zawsze są rozstrzygane wprost przez ustawodawcę ${ }^{39}$, w związku z czym doniosła rola $\mathrm{w}$ procesie ich wyjaśniania przypada doktrynie prawa. Przeprowadzenie wyczerpującej analizy prawnego mechanizmu tworzenia majątku wspólnego, zwłaszcza w odniesieniu do sytuacji nabywania do niego praw przez zachowania jednego tylko małżonka, wymagałoby znacznie obszerniejszego opracowania. Wydaje się jednak, że powołane wypowiedzi doktryny i przedstawione w niniejszym artykule argumenty ${ }^{40}$ dostatecznie potwierdzają dwie tezy: o potrzebie ponownego przemyślenia zasadności dominującego poglądu oraz o stałości, trwającego nawet mimo zachodzących przemian społeczno-gospodarczych, istotnego wpływu przepisów o małżeńskich ustrojach majątkowych na niemal wszystkie dziedziny obrotu cywilnoprawnego.

\section{STATUTORY REQUIREMENTS FOR THE ACQUIRER OF A SUBJECTIVE RIGHT AND THE ACQUISITION OF THE RIGHT TO THE COMMUNITY PROPERTY OF SPOUSES}

\author{
Summary
}

In certain situations, the acquisition of a subjective right requires, in addition to the occurrence of an appropriate legal event (e.g. conclusion of a contract), that the acquirer fulfils specific conditions, such as obtaining an administrative permit or acting in good faith. In the doctrine and case law, it is usually assumed that in the case of spouses remaining in the statutory joint system it is

$39 \mathrm{~Np}$. art. 2a ust. 3a ustawy z dnia 11 kwietnia 2003 roku o kształtowaniu ustroju rolnego (tekst jedn. Dz.U. z 2019 r. poz. 1362).

40 Oraz coraz częściej pojawiające się wypowiedzi krytyczne wobec dotychczasowego stanowiska orzecznictwa i nauki. 
sufficient for the right to be acquired to community property that only one spouse possesses the appropriate characteristic. However, this thesis does not deserve full approval, as it omits the wording and function of legal provisions introducing the said requirements.

Keywords: community property of the spouses, statutory matrimonial property regime, acquisition of a subjective right, good faith, acquisition of property by foreigners

\section{BIBLIOGRAFIA}

Bereza A., Nabycie nieruchomości do majątku objętego matżeńska wspólnościa ustawowa, jeżeli jeden z matżonków ma status cudzoziemca, ,Rejent” 2004, nr 3-4.

Dyoniak A., Ustawowy ustrój majątkowy matżeński, Wrocław 1985.

Gniewek E., Kodeks cywilny. Ksiega druga. Własność i inne prawa rzeczowe. Komentarz, Kraków 2001.

Gołębiowski K., [w:] Kodeks cywilny. Komentarz, red. E. Gniewek, P. Machnikowski, Warszawa 2019.

Gołębiowski K., Zarząd majątkiem wspólnym matżonków, Warszawa 2012.

Hartwich F., Nabycie własności nieruchomości przez cudzoziemca bez zezwolenia, „Monitor Prawniczy" 2002, nr 5.

Ignatowicz J., Prawo rodzinne, Warszawa 2000.

Jędrejek J., Nabycie własności nieruchomości przez matżonka będącego cudzoziemcem, „Nieruchomości” 2008, nr 11.

Machnikowski P., [w:] Kodeks cywilny. Komentarz, red. E. Gniewek, P. Machnikowski, Warszawa 2019.

Nazar M., [w:] System Prawa Prywatnego, t. 11. Prawo rodzinne, red. T. Smyczyński, Warszawa 2014.

Piątowski J.S., [w:] System prawa rodzinnego i opiekuńczego, red. J.S. Piątowski, Wrocław 1985.

Piątowski J.S., Glosa do uchwaty Sądu Najwyższego z dnia 24 września 1970 r., III CZP 55/70, „Orzeczenia Sądów Polskich i Komisji Arbitrażowych” 1973, nr 6.

Pyziak-Szafnicka M., [w:] System Prawa Prywatnego, t. 1. Prawo cywilne - część ogólna, red. M. Safjan, Warszawa 2007.

Radwański Z., Prawo cywilne - część ogólna, Warszawa 2005.

Stelmachowski A., [w:] System Prawa Prywatnego, t. 3. Prawo rzeczowe, red. T. Dybowski, Warszawa 2007.

Sychowicz M., [w:] Kodeks rodzinny i opiekuńczy. Komentarz, red. K. Piasecki, Warszawa 2006.

Szpunar A., Nabycie własności ruchomości od nieuprawnionego, Kraków 1999.

Wereśniak-Masri I., Nabywanie nieruchomości przez cudzoziemców w Polsce, Warszawa 2017.

Wolter A., Ignatowicz J., Stefaniuk K., Prawo cywilne. Zarys części ogólnej, Warszawa 2002.

Przegląd Prawa i Administracji CXX, 2020, cz. 1 i 2

(C) for this edition by CNS 